\title{
BUSINESS SCHOOLS QUALITY CULTURE PRACTICES AND FACULTY JOB SATISFACTION
}

Azmi B Ahmad, Nathaniel Corry, Southern Utah University, U.S.A.

\author{
dx.doi.org/10.18374/IJSM-20-1.5
}

\begin{abstract}
People are an organization's greatest asset. Having great people supported by a great organizational culture is a recipe for success. For this reason, more and more organizations are adopting the Total Quality Management (TQM) philosophy to effectively manage their employees and to change their organizational culture. The TQM philosophy focuses on people management practices as its foundation to achieve high quality products and services. The idea is that quality should not be forced, but should only be achieved through workers who are highly committed, highly motivated, genuinely have pride in their work, and have the desire to continuously do their best throughout their career in the organization. This paper is a result of a study to show that adopting the TQM quality practices should result in better employee job satisfaction. A random survey on business schools' faculty members throughout the United States was performed to find out whether or not schools' quality culture practices, such as empowerment, teamwork, continuous improvement, continuous training, and employee involvement could result in the respondents having greater job satisfaction.
\end{abstract}

Keywords: Quality Management, Job Satisfaction, Quality Culture, Business Schools, TQM 